\title{
An assessment of the physico-chemical parameters of Oran sebkha basin
}

\author{
Boualla Nabila • Benziane Ahmed • Moussa Kacem
}

Received: 25 July 2013/ Accepted: 17 December 2013/Published online: 1 March 2014

(C) The Author(s) 2014. This article is published with open access at Springerlink.com

\begin{abstract}
Growing populations and increasing industrialization cause increase in living standard, which result in decrease in the quality of water and may put stresses on natural waters by impairing both the quality of the water and the hydrological budget. This research aims at determining the origin of the chemical elements of groundwater from the Oran sebkha basin. It applies the inverse geochemical modeling to derive the sources of variation in the hydrochemistry by Belkhiri et al. (doi:10.1016/j.geoderma.2010. 08.016, 2010). Fifty-five water samples were selected from different point in Oran sebkha basin for sampling purpose in July 2011. Physico-chemical parameters such as $\mathrm{pH}$ and electric conductivity were measured in situ. Moreover, chloride, sulfate, alkalinity, calcium, magnesium, sodium and potassium were measured in the laboratory. Inverse geochemical models of the statistical groups were developed using PHREEQC to elucidate the chemical reactions controlling water chemistry. The inverse geochemical modeling demonstrated that relatively few phases are required to derive water chemistry in the area. In a broad sense, the reactions responsible for the hydrochemical
\end{abstract}

\section{B. Nabila ( $\square)$}

Oran, Algeria

e-mail: nibrasnabila@yahoo.fr

\section{B. Ahmed}

Department Civil Engineering, Laboratory Materials,

Soil and Thermal, University of Science and Technology,

USTOMB, Oran 31000, Algeria

e-mail: ah.benziane@gmail.com

\section{Kacem}

Department Earth Sciences, Laboratory Geodynamics basins and sediment budget, University of Science and Technology, USTOMB, Oran 31000, Algeria

e-mail: moussakacem@yahoo.fr evolution in the area fall into three categories: (1) dissolution of evaporite minerals; (2) precipitation of carbonate minerals; and (3) weathering reactions of silicate minerals by Belkhiri et al. (doi:10.1016/j.geoderma.2010.08.016, 2010). The high values of the physico-chemical parameters of water obtained in the present study sites indicate a variation in the physico-chemical parameters demonstrated that relatively few phases are required to derive water chemistry in the area. Range of values was found as $\mathrm{pH}$ (5.1-7.6), conductivity $\left(720-15,820 \mu \mathrm{S} \mathrm{cm}^{-1}\right)$, chloride (994-7,810 $\left.\mathrm{mg}^{-1}\right)$, sulfate $\left(6.1-112.4 \mathrm{mg} \mathrm{l}^{-1}\right)$, alkalinity (421-19,962 $\mathrm{mg} \mathrm{l}^{-1}$ ), calcium (80-680 $\mathrm{mg}^{-1}$ ), magnesium (212.4-4,525 $\mathrm{mg} \mathrm{l}^{-1}$ ), sodium (124.2-4,687.4 $\mathrm{mg}^{-1}$ ) and potassium (0.9-42.5 $\left.\mathrm{mg}^{-1}\right)$.

Keywords Physico-chemical parameters - Water . Sebkha

\section{Introduction}

The availability of good quality water is an indispensable feature for preventing diseases and improving quality of life (Oluduro and Adewoye 2007). Natural water contains some types of impurities whose nature and amount vary with source of water (Drever 1988).

Water quality characteristic of aquatic environment arises from a multitude of physical, chemical and biological interactions (Deuzuane 1979). The water bodies, rivers, lakes, dams and estuaries are continuously subject to dynamic change with respect to the geological age, geochemical characteristics and anthropogenic influences.

This is demonstrated by continuous circulation, transformation and accumulation of energy and matter through the medium of living things and their activities. The 
Fig. 1 Localization of sampling points in study area

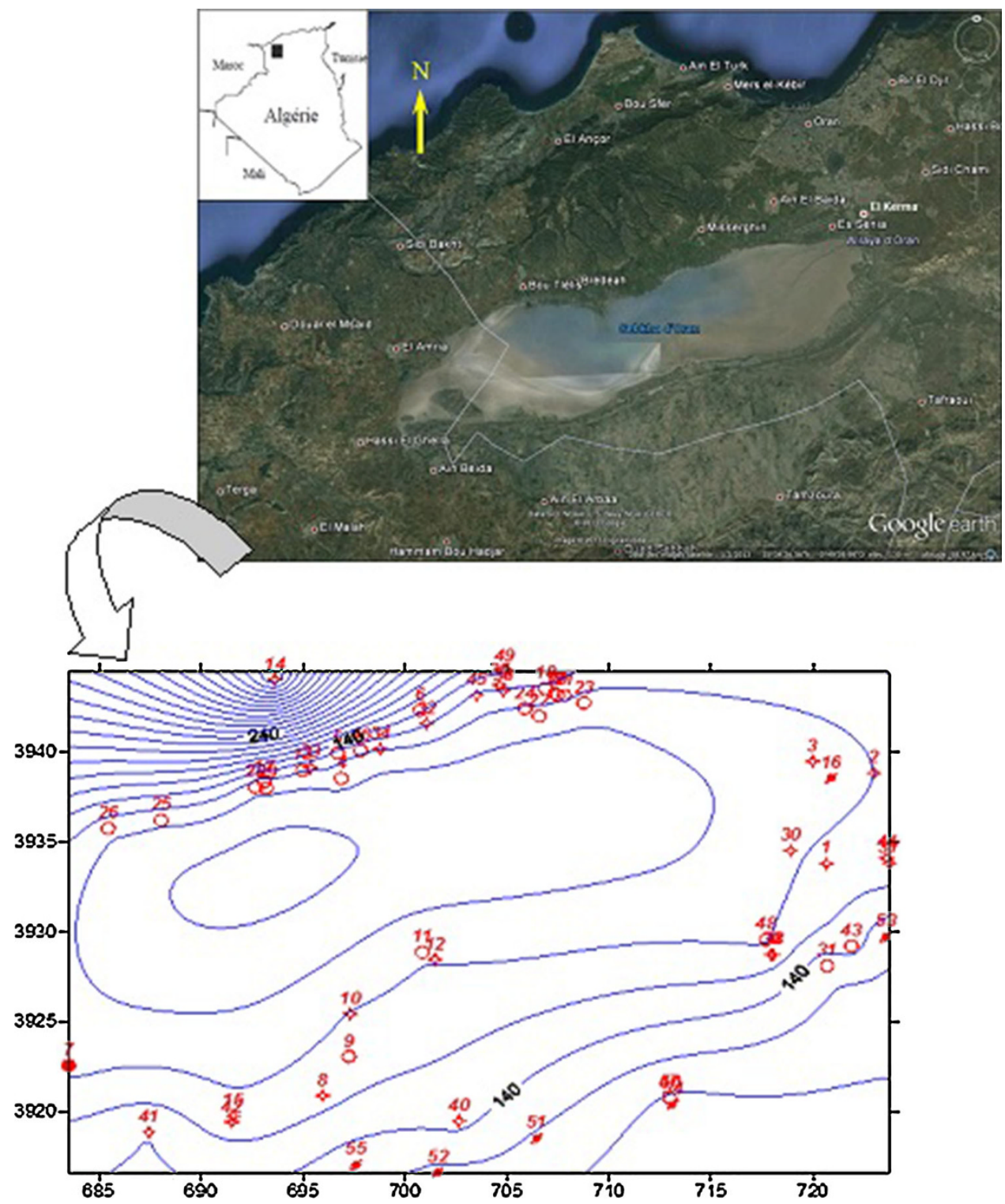

dynamic balance in the aquatic ecosystem is upset by human activities, resulting in pollution which is manifested dramatically as fish kill, offensive taste, odor, color and unchecked aquatic weeds. The objective of the monitoring studies undertaken for water body is to assess variation in water quality.

The soundness or validity of the results in the inverse modeling depends on a valid conceptualization of the groundwater system, validity of the basic hydrochemical concepts and principles, accuracy of input data into the model, and level of understanding of the geochemical processes in the area (Güler and Thyne 2004).

Variation in groundwater chemistry is mainly a function of the interaction between the groundwater and the mineral composition of the aquifer materials through which it moves. Hydrochemical processes, including dissolution, precipitation, ion exchange, sorption, and desorption, together with the residence time occurring along the flow path, control the variation in chemical composition of groundwater (Apodaca et al. 2002). The zone of study covers: the great Oran sebkha basin (with an area of $1,878 \mathrm{~km}^{2}$ ); the sebkha itself (with an area of $298 \mathrm{~km}^{2}$ ) and the stretches (over $40 \mathrm{~km}$ long and $6-13 \mathrm{~km}$ wide). The zone is located in the Central Coastal Oran basin and is bounded by: the Djebel Murdjadjo (530 m) in the north, the Mount Tessala $(1,061 \mathrm{~m})$ in the south, the plain oued Tlelat in the east, and oued Mellah in the west (Fig. 1). The integrated geological study (sedimentology, geomorphology, tectonic, hydrogeology) permitted to determine factors which conditioned its setting up, since the lower-middle Miocene (Burdigalian-Langhian-Serravallian); emerged in the beginning of the Tortonian age, then it met and until the 
Pleistocene under a marine regime that evolved toward a continental regime since the superior Pleistocene. The southward swing of the northern area (Murdjadjo south side) at the Soltanian age would have been the main reason of the Sebkha of Oran endoreism and its subsequently closing (full) with the setting up of the wind accumulations.

\section{Materials and methods}

In order to characterize the groundwater quality in the dry season, a sampling network was chosen to allow the acquisition of representative data on the spatial and temporal variability (Fig. 1). This network covers the entire basin upstream to downstream and consists of a set of points of water wells, boreholes and springs.

Water withdrawals were made at low waters. The samples were collected during the period of 04-20 July 2011 where comprehensive analyses were performed. The parameters that have been measurement are: $\mathrm{pH}$ and electrical conductivity (EC) were measured in the field using a multi-parameter HANNA ( $\mathrm{pH}$ meter HANNA instrument HI 9811). Subsequently, the samples were analyzed in the laboratory for their chemical constituents such as calcium, magnesium, sodium, potassium, chloride, bicarbonate and sulfate. This was achieved using standard methods as suggested by Rodier (1996). $\mathrm{Ca}^{+2}, \mathrm{Mg}^{+2}, \mathrm{HCO}_{3}{ }^{-}$and $\mathrm{Cl}^{-}$ were analyzed by volumetric titrations. Concentrations of $\mathrm{Ca}^{+2}$ and $\mathrm{Mg}^{+2}$ were estimated titrimetrically using $0.05 \mathrm{~N}$ EDTA and those of $\mathrm{HCO}_{3}{ }^{-}$and $\mathrm{Cl}$ by $\mathrm{H}_{2} \mathrm{SO}_{4}$ and $\mathrm{AgNO}_{3}$ titration, respectively. Concentrations of $\mathrm{Na}^{+}$and $\mathrm{K}^{+}$were measured using an Ionogram (Model: Ionogram Easy lyte $\mathrm{Na} / \mathrm{K} / \mathrm{Cl}, 800 \mathrm{ml}$, MEDICA 001384-001 R2 Analyser, 12160/12014-05) and that of sulfate by Spectrometer method (Model: Spectrometer UV Optizen 2120 UV). The results were tabled for interpretation.

In the literature, many different methodologies have been applied to study, evaluate and characterize the sources of variation in groundwater geochemistry. Among these methods is the inverse geochemical modeling in PHREEQC (Parkhurst and Appelo 1999) which is based on a geochemical mole-balance model and calculates the phase mole transfers (the moles of minerals and gases that must enter or leave a solution).

\section{Results and discussion}

The physico-chemical parameters obtained from analysis of water samples from Oran sebkha basin are presented in Table 1 . The groundwater samples of the study area have $\mathrm{pH}$ values ranging from 5.1 to 7.6 , which indicate that the groundwater is alkaline. The electrical conductivity (EC)
Table 1 The physico-chemical parameters of water samples from Oran sebkha basin

\begin{tabular}{lllllll}
\hline Parameter & Aver. & Min. & Max. & $\begin{array}{l}\text { Standard } \\
\text { deviation }\end{array}$ & Median & $\begin{array}{l}\text { WHO } \\
(2004)\end{array}$ \\
\hline $\mathrm{pH}$ & 6.9 & 5.1 & 7.6 & 0.4 & 6.9 & $6.5-9.2$ \\
$\mathrm{EC}\left(\mu \mathrm{S} \mathrm{m}^{-1}\right)$ & $5,905.3$ & 720 & 15,820 & $3,303.7$ & 5,710 & - \\
$\mathrm{Cl}^{-}\left(\mathrm{mg} \mathrm{l}^{-1}\right)$ & $2,472.7$ & 994 & 7,810 & $1,180.8$ & $2,307.5$ & 250 \\
$\mathrm{SO}_{4}^{-2}\left(\mathrm{mg} \mathrm{l}^{-1}\right)$ & 26.1 & 6.1 & 112.4 & 20.3 & 22 & 250 \\
$\mathrm{HCO}_{3}^{-}$ & 4,764 & 421 & 19,962 & 4,128 & 3,288 & 240 \\
$\left(\mathrm{mg} \mathrm{l}^{-1}\right)$ & & & & & & \\
$\mathrm{Na}^{+}\left(\mathrm{mg} \mathrm{l}^{-1}\right)$ & 863.7 & 124.2 & $4,687.4$ & 717.7 & 733.7 & 200 \\
$\mathrm{~K}^{+}\left(\mathrm{mg} \mathrm{l}^{-1}\right)$ & 8.6 & 0.9 & 42.5 & 8.4 & 6.2 & 200 \\
$\mathrm{Ca}^{+2}\left(\mathrm{mg} \mathrm{l}^{-1}\right)$ & 304.4 & 80 & 680 & 131.9 & 280 & 200 \\
$\mathrm{Mg}^{+2}\left(\mathrm{mg} \mathrm{l}^{-1}\right)$ & $1,258.8$ & 212.4 & 4,525 & 920.2 & 956.4 & 150 \\
\hline
\end{tabular}

values ranged from 720 to $15,820 \mu \mathrm{S} \mathrm{cm}{ }^{-1}$ which is the characteristic of mixed water $\left(\mathrm{Ca}-\mathrm{Mg}-\mathrm{Cl}-\mathrm{HCO}_{3}\right)$. The gradual increase of conductivity denotes a significantly lateral input of wastewater with higher conductivity (Trinh 2003). The order of abundance of the major cations is $\mathrm{Mg} \geq \mathrm{Na} \geq \mathrm{Ca} \geq \mathrm{K}$ and all samples exceeded the desirable limit of $\mathrm{Ca}, \mathrm{Mg}$ and $\mathrm{Cl}$ for drinking water, but the sulfate concentrations are all below health guidelines (WHO 2004) (Table 1).

In all water samples, a critical look at the results revealed that the values of these physico-chemical parameters are higher in the basin based on geological position; discharges of industrial wastewater and contamination of the groundwater by seawater were excluded as the source of high concentrations. The quantity of waste in different phases of a natural aquatic system is reflected by the level of hardness, alkalinity and other physico-chemical parameters. The higher values of all these physico-chemical parameters than those obtained could be a result of washing away of sulfate based fertilizers into the river (Ipinmoroti and Oshodi 1993; Vogel 1970).

Inferring the sources of solutes in groundwater using simple mass balance approaches does not provide unequivocal results, a reasonable way of constraining the processes that might influence the major ion chemistry. The controls on the hydrochemical evolution of groundwater largely depend on the chemistry of the recharging water, water aquifer matrix interaction (cation exchange), or both, as well as groundwater residence time within the aquifer (Garrels and MacKenzie 1971).

Three general processes that contribute to the generation of solutes in groundwater are: evaporate dissolution, carbonate dissolution, and silicate weathering (Garrels and MacKenzie 1971). The chemistry of the evolving water depends not only on the bulk chemistry of the matrix but also on the rate of weathering. Meybeck (1987) commented 


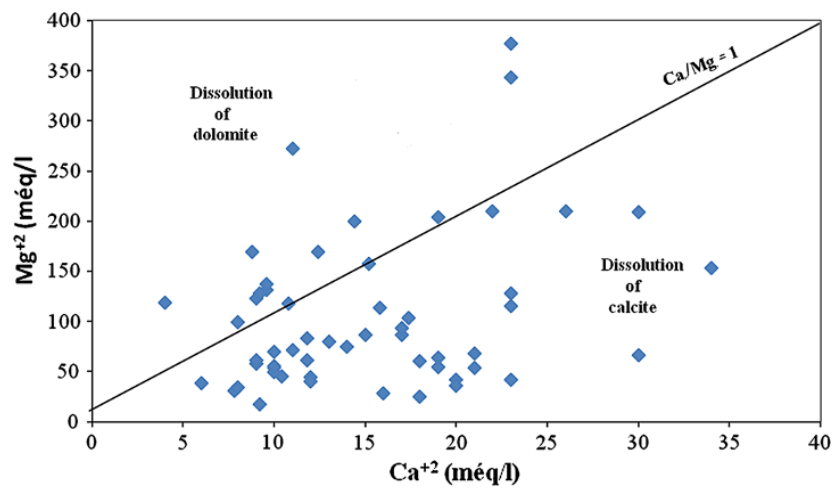

Fig. 2 Sample number versus $\mathrm{Ca}^{2+} / \mathrm{Mg}^{2+}$

that weathering rates of evaporates and carbonates are up to 80 times and $\sim 12$ times, respectively, faster than silicate weathering rates. Hence, even relatively minor proportions of carbonates and evaporates can significantly influence water chemistry.

The study of the $\mathrm{Ca}^{2+}\left(\mathrm{mEq} \mathrm{1}^{-1}\right) / \mathrm{Mg}^{2+}\left(\mathrm{mEq} \mathrm{l}^{-1}\right)$ ratio of groundwater from the area of study suggests the dissolution of dolomite present in the alluvium (Fig. 2). That is, if the ratio $\mathrm{Ca}^{2+} / \mathrm{Mg}^{2+}=1$, dissolution of dolomite should occur, whereas a higher ratio is indicative of greater calcite contribution (Maya and Loucks 1999). The points located below the line $\left(\mathrm{Ca}^{2+} / \mathrm{Mg}^{2+}=1\right)$ indicate the dissolution of dolomite. The samples have a ratio between 0.03 and 0.72 indicating the dissolution of dolomite. Dissolved carbonates (calcite and dolomite) occur predominantly in the form of $\mathrm{HCO}_{3}{ }^{-}$, due to the $\mathrm{pH}$ range. The solubility of calcite and dolomite is largely controlled by $\mathrm{CO}_{2}$ fugacity and $\mathrm{pH}$, according to the reactions:

$$
\begin{aligned}
& \mathrm{CaCO}_{3}+\mathrm{CO}_{2}(\mathrm{~g})+\mathrm{H}_{2} \mathrm{O}=\mathrm{Ca}^{2+}+2 \mathrm{HCO}_{3}^{-} \\
& \mathrm{Ca} 1-x \mathrm{Mg}_{x} \mathrm{CO}_{3}+\mathrm{CO}_{2}(\mathrm{~g})+\mathrm{H}_{2} \mathrm{O} \\
& =(1-x) \mathrm{Ca}^{2+}+x \mathrm{Mg}^{2+}+2 \mathrm{HCO}_{3}{ }^{-}
\end{aligned}
$$

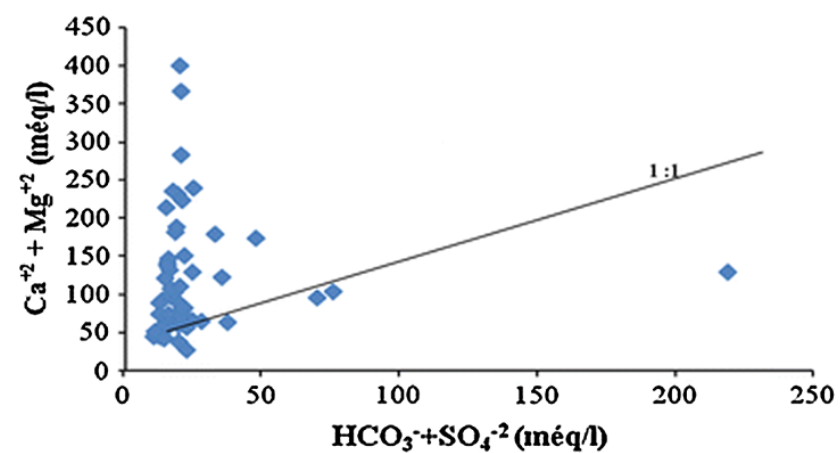

Fig. $3 \mathrm{Ca}^{2+}+\mathrm{Mg}^{2+}$ versus $\mathrm{SO}_{4}^{-2}+\mathrm{HCO}_{3}{ }^{-}$

The plot of $\mathrm{Ca}^{2+}+\mathrm{Mg}^{2+}$ versus $\mathrm{SO}_{4}^{-2}+\mathrm{HCO}_{3}{ }^{-}$will be close to the 1:1 line if the dissolutions of calcite, dolomite, anhydrite and gypsum are the dominant reactions in a system (Maya and Loucks 1999). Ion exchange tends to shift the points to right due to an excess of $\mathrm{SO}_{4}^{-2}+\mathrm{HCO}_{3}{ }^{-}$ (Cerling et al. 1989; Fisher and Mulican 1997; McLean and Jankowski 2000). If reverse ion exchange is the process, it will shift the points to the left due to a large excess of $\left(\mathrm{Ca}^{2+}+\mathrm{Mg}^{2+}\right)$ over $\mathrm{SO}_{4}^{-2}+\mathrm{HCO}_{3}{ }^{-}$. The plot of $\mathrm{Ca}^{2+}+\mathrm{Mg}^{2+}$ versus $\mathrm{SO}_{4}^{-2}+\mathrm{HCO}_{3}^{-}$shows that the all samples are located in the left side due to an excess of $\left(\mathrm{Ca}^{2+}+\mathrm{Mg}^{2+}\right)$ (Belkhiri et al. 2010) (Fig. 3).

An Na (méq L ${ }^{-1}$ )-normalized $\mathrm{Ca}^{2+}\left(\right.$ méq L ${ }^{-1}$ ) versus $\mathrm{HCO}_{3}{ }^{-}$(méq L ${ }^{-1}$ ) and plot $\mathrm{Mg}^{2+}$ (méq L ${ }^{-1}$ ) plot (Figs. 4,5 ) (Gaillardet et al. 1999) shows that the samples range from being influenced by silicate weathering to carbonate dissolution. The relation between Na-normalized $\mathrm{Ca}^{2+}, \mathrm{HCO}_{3}{ }^{-}$ and $\mathrm{Mg}^{2+}$ shows that although most of the $\mathrm{Mg}$ may have been derived from carbonate dissolution, some have a silicate source (Belkhiri et al. 2010).

The saturation indices (calculated by PHREEQC) of some of the common mineral phases are presented in Table 2, which clearly shows that the groundwater is
Fig. 4 Na-normalized $\mathrm{Ca}^{2+}$ and $\mathrm{HCO}_{3}{ }^{-}\left(\mathrm{HCO}_{3} / \mathrm{Na}\right)(\mathrm{mEq}$ $1^{-1} / \mathrm{mEq}^{-1}$ )

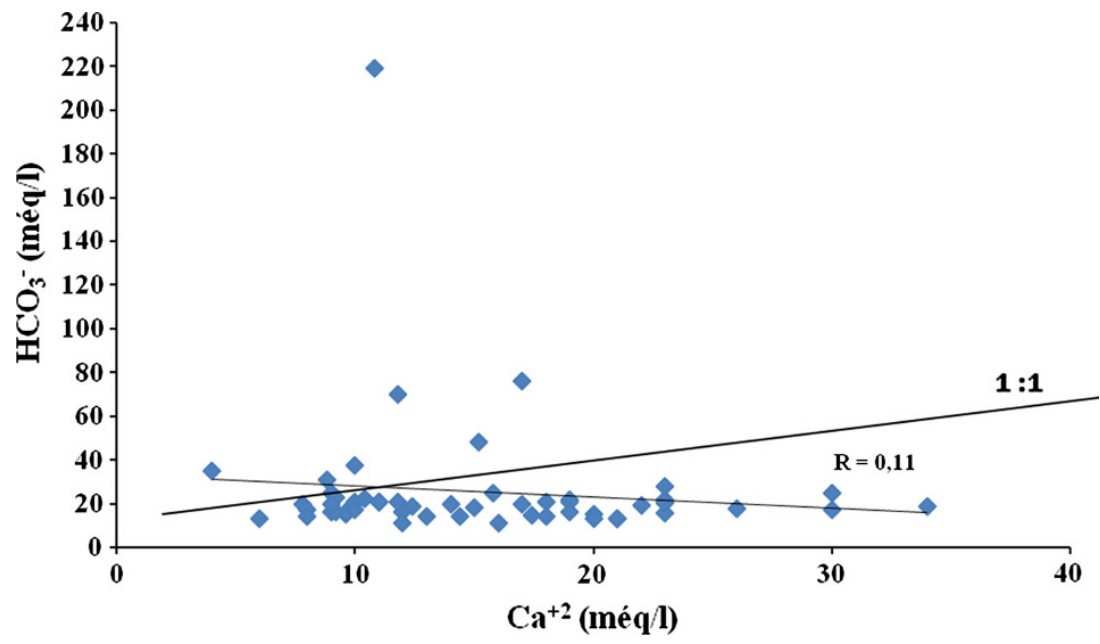


Fig. 5 Na-normalized $\mathrm{Ca}^{2+}$ and $\mathrm{Mg}^{2+}$

Table 2 Saturation indices of the water samples from Oran sebkha basin calculated by PHREEQC

Fig. 6 Piper diagram showing groundwater classification (Piper 1994)

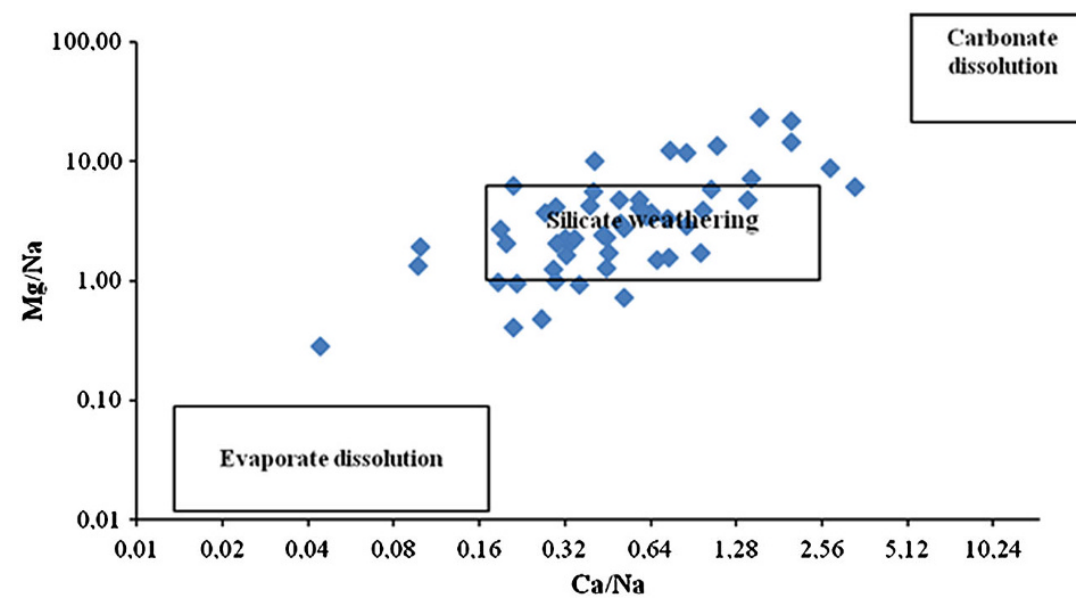

\begin{tabular}{llr}
\hline Phase & Stoichiometry & Average \\
\hline Anhydrite & $\mathrm{CaSO}_{4}$ & -2.19 \\
Aragonite & $\mathrm{CaCO}_{3}$ & 0.84 \\
Calcite & $\mathrm{CaCO}_{3}$ & 0.98 \\
Dolomite & $\mathrm{CaMg}\left(\mathrm{CO}_{3}\right)_{2}$ & 2.87 \\
Gypsum & $\mathrm{CaSO}_{4}: 2 \mathrm{H}_{2} \mathrm{O}$ & -1.98 \\
\hline
\end{tabular}

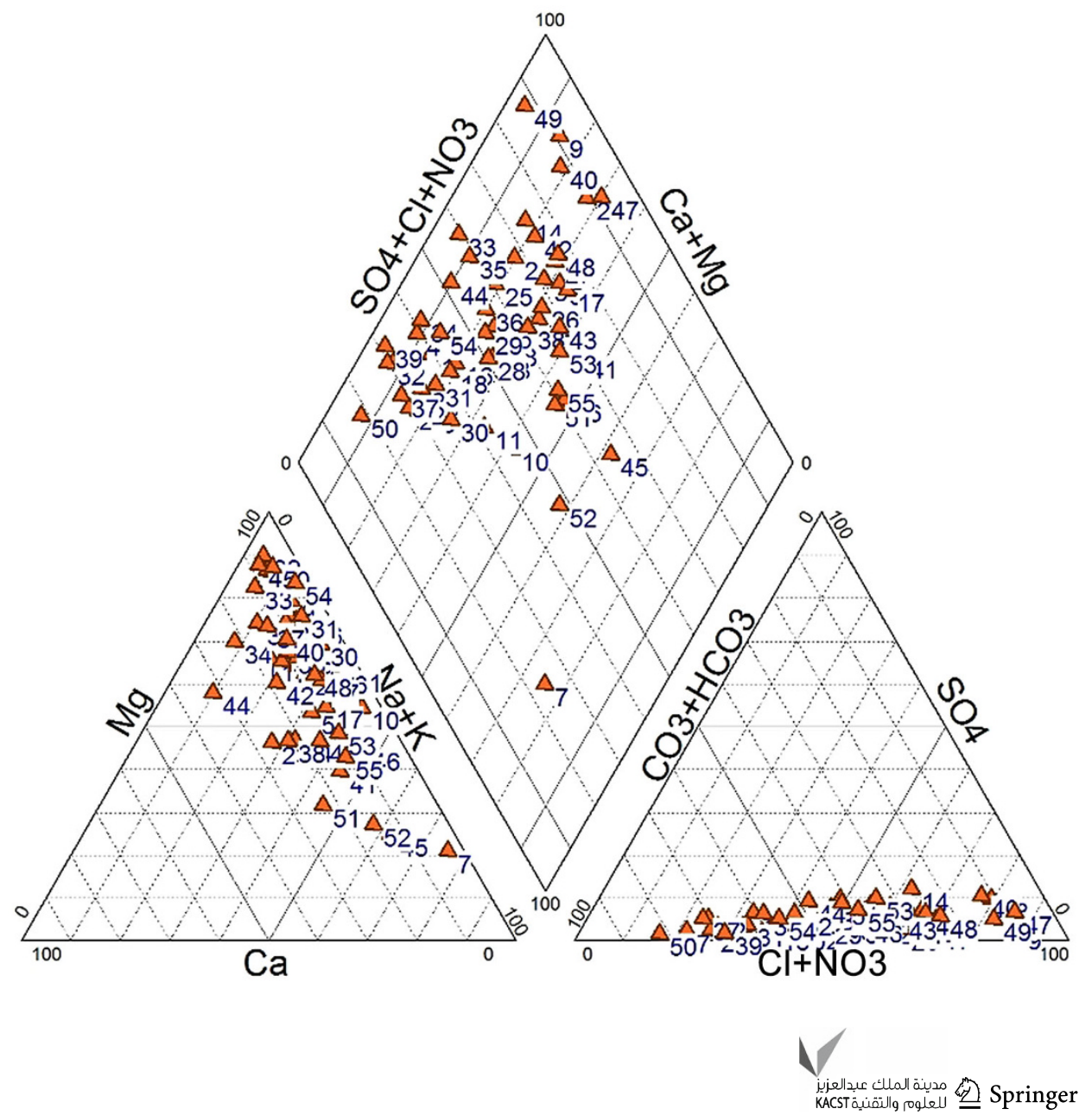


generally supersaturated with respect to most of the carbonate phases and is most probably responsible for the composition of the groundwater (Belkhiri et al. 2010).

The results of saturation calculations show that all the points are under saturated with anhydrite and gypsum, and halite mineral phases are minor or absent in the area, suggesting that their soluble components $\mathrm{Na}^{+}, \mathrm{Cl}^{-}, \mathrm{Ca}^{2+}$ and $\mathrm{SO}_{4}^{-2}$ concentrations are not limited by mineral equilibrium. In contrast, aragonite, calcite and dolomite reach saturation as groundwater chemistry evolves along the groundwater flow paths. The groundwater in the studied area evolves from less saline $\mathrm{Ca}-\mathrm{Mg}-\mathrm{HCO}_{3}$ water to blended $\mathrm{Mg}-\mathrm{Ca}-\mathrm{HCO}_{3}-\mathrm{Cl}$ water to brackish $\mathrm{Mg}-\mathrm{Ca}-\mathrm{Cl}-$ $\mathrm{HCO}_{3}$ water along the topographic flow path. Inverse geochemical modeling along groundwater flow paths indicates the dissolution of evaporite minerals, precipitation of carbonate minerals and weathering reactions of silicate minerals (Table 1; Fig. 6) (Belkhiri et al. 2010).

\section{Conclusion}

The results of this study show that analysis of hydrochemical data using statistical techniques such as inverse geochemical modeling of the statistical clusters can help to elucidate the geological factor controlling water chemistry.

The groundwater in the studied area evolves from less saline $\mathrm{Ca}-\mathrm{Mg}-\mathrm{HCO}_{3}$ water to blended $\mathrm{Mg}-\mathrm{Ca}-\mathrm{HCO}_{3}-\mathrm{Cl}$ water to brackish $\mathrm{Mg}-\mathrm{Ca}-\mathrm{Cl}-\mathrm{HCO}_{3}$ water along the topographic flow path.

The analysis indicates that the water of Oran sebkha basin is characterized with moderate alkalinity in the investigated period. Mineral saturation indices calculated from both major ions indicate that the groundwater is generally supersaturated with respect to most of the carbonate and silicate phases and is most probably responsible for the composition of the groundwater.

Inverse geochemical modeling along groundwater flow paths indicates the dissolution of evaporite minerals, precipitation of carbonate minerals and weathering reactions of silicate minerals.

Open Access This article is distributed under the terms of the Creative Commons Attribution License which permits any use, distribution, and reproduction in any medium, provided the original author(s) and the source are credited.

\section{References}

Apodaca LE, Jeffrey BB, Michelle CS (2002) Water quality in shallow alluvial aquifers, Upper Colorado River Basin, Colorado, 1997. J Am Water Res Assoc 38(1):133-143
Belkhiri L, Boudoukha A, Mouni L, Baouz L (2010) Application of multivariate statistical methods and inverse geochemical modeling for characterization of groundwater-a case study: Ain Azel plain (Algeria). d 0016-7061/\$—see front matter (C) 2010 Elsevier B.V. All rights reserved. doi:10.1016/j.geoderma. 2010.08.016

Cerling TE, Pederson BL, Damm KLV (1989) Sodium-calcium ion exchange in the weathering of shales: implications for global weathering budgets. Geology 17:552-554

Deuzuane J (1979) Handbook of drinking water quality. Indiana University Press, Bloomington, pp 3-17

Drever JI (1988) The Geochemistry of Natural Waters. Prentice-Hall, Upper Saddle River

Fisher RS, Mulican WFIII (1997) Hydrochemical evolution of sodium-sulfate and sodium-chloride groundwater beneath the Northern Chihuahuan desert, Trans-Pecos, Rexas, USA. Hydrogeol J 10(4):455-474

Gaillardet J, Dupre B, Louvat P, Allegre CJ (1999) Global silicate weathering and $\mathrm{CO}_{2}$ consumption rates deduced from the chemistry of large rivers. Chem Geol 159:3-30

Garrels RM, MacKenzie FT (1971) Evolution of sedimentary rocks. Norton, New York

Güler C, Thyne GD (2004) Hydrologic and geologic factors controlling surface and Groundwater chemistry in Indian wells-Owens Valley area, southeastern California, USA. J Hydrol 285:177-198

Ipinmoroti K, Oshodi O (1993) Determination of trace metals in fish, associated wanted and soil sediments fresh fish ponds. Discov Innov 5:138

Maya AL, Loucks MD (1999) Solute and isotopic geochemistry and groundwater flow in the Central Wasatch Range, Utah. J Hydrol 172:31-59

McLean W, Jankowski J (2000) Groundwater quality and sustainability in an alluvial aquifer, Australia. In: Sililo et al (ed), Proceedings XXX IAH congress on Groundwater: Past Achievements and Future Challenges. Cape Town South Africa 26th November-1st December 2000. AA Balkema, Rotterdam, Brookfield

Meybeck M (1987) Global chemical weathering from surficial rocks estimated from river dissolved loads. Am J Sci 287:401-428

Oluduro AO, Adewoye BI (2007) Efficiency of moringa Oleifera Sead extract on the microflora of surface and ground water. J Plant Sci 6:438-453

Parkhurst DL, Appelo CAJ (1999) User's guide to PHREEQC (Version 2)-A computer program for speciation, batch-reaction, one-dimensional transport, and inverse geochemical calculations. United States geological survey, water resources investigations report 99-4259, Washington, DC, p 326

Piper AM (1994) A graphic procedure in geochemical interpretation of water analyses. Am Geophys Union Trans 25:914-923

Rodier J (1996) L'analyse de l'eau, eaux naturelles, eaux résiduaires, eau de mer. 8 édition Dunod, Paris

Trinh AD (2003) Étude de la qualité des eaux d'un hydro système fluvial urbain autour de Hanoi (Vietnam); Suivi expérimental et modélisation. Thèse de doctorat de Université Joseph FourierGrenoble 1 (France) et Centre National des Sciences et de la Technologie (Vietnam)

Vogel I (1970) A text book of inorganic analysis published by Harley and Sons, 4th edn. p 148

WHO (2004) [Online] Available: www.who.int/water_sanitationhealth/publications/facts2004/en/index.html. World Health Organization (WHO) (2004) Guidelines for Drinking Water Quality, vol 1 Recommendations, 3rd edn. WHO, Geneva 